\title{
Review: Two Text-Books of Seismology
}

Author(s): R. D. O.

Review by: R. D. O.

Source: The Geographical Journal, Vol. 31, No. 4 (Apr., 1908), pp. 433-434

Published by: geographicalj

Stable URL: http://www.jstor.org/stable/1777856

Accessed: 26-06-2016 18:24 UTC

Your use of the JSTOR archive indicates your acceptance of the Terms \& Conditions of Use, available at

http://about.jstor.org/terms

JSTOR is a not-for-profit service that helps scholars, researchers, and students discover, use, and build upon a wide range of content in a trusted digital archive. We use information technology and tools to increase productivity and facilitate new forms of scholarship. For more information about JSTOR, please contact support@jstor.org.

The Royal Geographical Society (with the Institute of British Geographers), Wiley are collaborating with JSTOR to digitize, preserve and extend access to The Geographical Journal 
eastern coast of the continent there is a broad strip of more luxuriant plant-growth, with evea a true rain-forest in one part. To the north-west and in the south along the great Australian bight, the steppe-like character of the plateau-vegetation reaches the coast. The south-western corner has only a narrow strip of hygrophil vegetation. Towards the end of the book Dr. Diels discusses the relation of the flora of extra-tropical Western Australia to other parts of Australia, and to other parts of the world. This flora is typically Australian, and thus shows distinct affinities with the eastern and northern districts. It exhibits, however, no real connection with any other part of the Earth. On the whole, also, there are very great differences between the vegetation of the Cape and that of Western Australia, although affinities have always been made much of. But the difference in species and types of vegetation is really more marked than the similarity. What there is of the latter may be explained by assuming a far-back common origin from an ancient southern-hemisphere flora, or by development along analogous lines. The working out of the history and development of these two floral districts is one of the important problems of plant-geography.

O. V. D.

\section{MATHEMATICAL AND PHYSICAL GEOGRAPHY.}

Two Text-books of Seismology.

(1) 'Earthquakes: an introduction to Seismic Geology.' By William Herbert Hobbs. New York: D. Appleton \& Co. 1907. P. xxxi. and 336, 24 Plates, 309 Illustrations in Text. Price $\$ 2$ net.

(2) 'La Science Séismologique. Les tremblements de Terre,' aveo une Préface par M. Ed. Suess. Par Comte de Montessus de Ballore. Paris: Armand Colin. 1907. Pp. viii. and 579, 63 Plates, 540 Illustrations in Text. Price $16 \mathrm{fr}$.

Ne sutor ultra crepidam is a maxim which would le 2 do stagnation in science if carried to an extreme, but the cobbler who takes up another trade should learn it thoroughly before he begins to teach, and this Prof. Hobbs has not done. A geologist of reputation, he has developed a theory of earthquake origin which we accept in part, though not entirely; but as regards the science of seismology as a whole, his acquaintance with the work which has been done is imperfect, and as a guide his book is frequently misleading by its omissions. The title would lead us to expect a full treatment of the geographical aspects of earthquakes, but even here he passes by much of the work which has been done by others in establishing the fact that earthquake origins are much more extended than was at one time supposed, and he attributes the discovery of the principle of steepest slopes to de Montessus instead of to Prof. Milne. This principle, that the regions of great seismic and volcanic activity are those in which the average surface slope is highest and steepest, is one which, like the continent of America, could not escape discovery; its truth is more important, from a scientific point of view, than the name of the man who first gave expression to it, but if this is mentioned at all, it is well to be accurate.

The Comte de Montessus de Ballore is a seismologist of established reputation, whose work has lain in the domain of statistical and geographical seismology. In writing a general treatise on the science, he has had to deal with subjects which lie beyond the province of his labours previous to his acceptance of the post of director of the Seismological Service of the Republic of Chile, but, having read nearly everything that has been written, and remembered nearly everything he has read, writing, moreover, with the lucidity and precision of a Frenchmon, he has produced a remarkably complete text-book of seismology. The only section with which we find serious fault is that dealing with instruments, where the want of experience in their use, or in the interpretation of their records, has led him 
into error in more than one instance. His explanation of the principle of the duplex pendulum is not that offered by the inventor, nor is it the correct one, and the illustration on p. 291 of the principle of the light and the heavy horizontal pendulum is curiously in error. The principle of the horizontal pendulum is the same whatever the weight, but it may be applied in two different systems of mechanical construction. In the one a boom is pivoted to a support, and maintained in a horizontal position by a wire or thread attached to some point along its length. This is the system adopted in what we may call the Japanese type of horizontal pendulum, since it was elaborated in that country, and is the system depicted as the principle of the heavy pendulum; but it is also the system adopted in the Milne instrument, which is, in proportion to its dimensions, the lightest in use. The other system of construction utilizes a rigid bracket-like framework, which is pivoted on two knife-edges. This system may be illustrated by the garden gate, and is the one figured as the principle of the light horizontal pendulum; it is, however, adopted in the heavy horizontal pendula used in Italy, and is the only system mechanically admissible where very heavy weights are concerned; it is also utilized in the v. Rebeur Paschwitz instrument, which is classed as a light pendulum, though its lightness is solely the result of its small dimensions, and in proportion to these it should be classed as a heavy pendulum. The praise of the Wiechert instrument goes too far, and some of the claims made for it oannot be substantiated; it is not astatic in reality, but only in name, nor does the damping of the pendular oscillation enable it to record the actual movement of the ground. In saying this we intend no dispraise; the instrument is an admirable one, and marks the introduction of what may be called a new principle, at any rate, a new method of applying an old principle, in the construction of seismographs, but this does not make all other patterns obsolete, or do away with their utility. The astronomer does not discard his transit instrument because it will not serve the purpose of an equatorial telescope, and so more than one type of instrument will continue to be required in seismology, and the free-swinging pendulum, whether vertical or horizontal, will still continue to be used and to be useful.

Apart from this chapter, the book deserves praise as an account of the present state of our knowledge of earthquakes, and we may especially commend the inclusion of two chapters dealing with the methods of construction to be avoided or adopted in countries subject to earthquakes. This is a practical application of the principles of seismology which is generally neglected in treatises of the science.

R. D. 0 .

\section{GENERAL.}

The Geological Society of London.

' The History of the Geological Society of London.' By H. B. Woodward. London: The Geological Society. 1907. Pp. xx., 336. With 23 Plates of Portraits, and 5 Plates of Medals. Price 7s. 6d. (to Fellows, 6s.).

The unique position of London has given its scientific societies the opportunities for exceptionally useful service; and probably no society has had a more profound influence on the science with which it is concerned than the Geological Society. It was established on November 13, 1807, when eleven men met at the Freenasons T'avern, and arranged to join periodically in a dinner at five o'clock, to be fullowed by a meeting for geological conference and discussion. The combined social and scientitic aims of the young society led to an almost immediate split in its ranks. Sir Humphrey Davy and Sir Joseph Banks held that the society was only int nded to be a "little geological dining club," which was not to encroach on the sphere of the Royal Society by the publication of a new scientific serial. According to those 